\title{
State Budget Balance, Public Debt, and International Norms
}

\author{
BUI THI MAI HOAI \\ University of Economics HCMC - maihoai@ueh.edu.vn \\ SU DINH THANH \\ University of Economics HCMC - dinhthanh@ueh.edu.vn \\ BUI DUY TUNG \\ University of Economics HCMC - tungbd@ueh.edu.vn
}

\section{ARTICLE INFO ABSTRACT}

Article history:

Received:

Aug. 272015

Received in revised form:

Jan. 302015

Accepted:

Sep. 152015

Keywords:

Budget balance, fiscal sustainability, public debt, cointegration.
A fiscal sustainability model requires that budget revenues and expenditures be in balance while government budget constraints, ensured. Yet, it becomes problematic while failing to address the dynamism of the budget constraints, associated with the government's role (i.e. extending its intervention may affect public debt and finance). On adopting approaches by Trehan and Walsh (1991) and Hakkio and Rush (1991), which empirically tests cointegration between government revenues and its spending, this study's aim is to assess the issue of public debt and fiscal sustainability in Vietnam. The findings, on the ground of analyzing institutional factors, demonstrate that no sustainability, as well as potential risk, is reflected by Vietnam's public debt and fiscal policy. 


\section{Introduction}

The issue of budget balance and public debt has attracted rapt attention of economists. The 2008's financial crisis and European sovereign debt crisis have sparked off numerous debates over the sustainability of budget balance and public debt, as well as budget control in accordance with international practices. Amid the context of public debt of countries in Europe Catrina (2012) argued that implementing the budget balance policy by means of budget cuts is economically unfeasible. Sustainability of public finance demands a mix of macro policies intended to limit the arbitrary intervention by politicians in the structure of government expenditures. Allen (2013), examining government spending and public debt of the US in relation to the role of accounting educators, indicated certain unsustainability recorded through the problem of government debt, whereas it is essential that timely action in public expenditures be implemented to combat grave economic problems. Allen (2013) also detailed that a profound understanding of accounting and basic understanding of other related disciplines as reflected by the accounting educators do help penetrate the landscape of public debt and government expenditures.

In Vietnam the State Budget Law dated December 2002 and Law on Public Debt Management enacted in 2009 established the principles of budget balance and public debt management. Based on these principles, developers of formal assessments in Vietnam agreed that the Vietnam's public debt is sustainable (MOF, 2014a). IMF (2010, 2014) argued that the state budget balance of Vietnam is much different from international practices; thus, the management of state budget lacks transparency and accountability. Nguyen (2013) suggested that to improve the budget balance of Vietnam it is necessary to diversify revenue sources, exploit domestic revenues, and also limit those from external dependencies, whereas allocation of expenditures should target essential areas, such as education, health, and infrastructure. According to the National Assembly Economic Committee and UNDP (2013), a major risk to the national public debt comes from domestic debt. Despite the large-scale foreign debt, the burden of annual debt repayment is relatively relieved in the following years due to low interest rates and long terms offered. Yet, only when exchange rates are stabilized may such a favorable condition be guaranteed in Vietnam.

In this study, with a primary aim to examine the level of fiscal and public debt sustainability in Vietnam, we adopt the Trehan and Walsh's (1991) and Hakkio and 
Rush's (1991) approaches in empirical tests on cointegration between government revenue and its spending. Additionally, analyses of institutional aspects and differences between domestic and international norms allow us to further detail the landscape of Vietnam's public debt and fiscal policy.

The paper is structured as follows. Section 2 reviews existing theories on budget balance as well as fiscal and public debt sustainability. The state of Vietnam's fiscal sustainability and public debt is detailed in Section 3, while Section 4 is designed for different empirical tests and assessment of the sovereign debt and fiscal vulnerability. Finally, in the last section we conclude the paper in addition to drawing a few implications.

\section{Review of budget balance and fiscal/public debt sustainability}

\subsection{Theories of budget balance and sustainability}

Balancing the state budget is defined as the determination of financial demands by the government in the fiscal year after the balance of budget revenues and expenditures. Essentially, budget balancing means tackling the deficit of state budget that should be financed via borrowing to achieve the objectives of fiscal policy (Blejer \& Cheasty, 1991).

The term 'fiscal sustainability' highlights the present value of total government spending equaling that of its revenues (Mendoza \& Oviedo, 2003). Thus, a country's fiscal policy is regarded as being sustainable if it satisfies various conditions of budget constraints (Alvarado et al., 2004). Theoretically, the fiscal sustainability implies that the observed net stock of the government's financial liabilities is consistent with fiscal solvency considerations (Mendoza \& Oviedo 2003). Given the intertemporal budget constraints, the sustainability is defined as the debt-to-GDP ratio returns to its original level(s) after excessive variation (Afonso, 2000). For a fiscal policy to be sustainable, after having accumulated debt in the past, the government must constantly maintain primary surpluses in the future. Similarly, Gunter (2003) and Burnside (2003) define the sustainability as a country's ability to fulfil its current and future debt service obligations in full without recourse to debt rescheduling or remission.

The issue of government budget constraints provides a basic framework for fiscal sustainability conditions. The budget constraint for period $t$ is presented as follows: 


$$
G_{t}+\left(1+r_{t-1}\right) B_{t-1}=B_{t}+T_{t}
$$

In Eq. $1 G_{t}$ is government spending on goods and services at period $t ; r_{t-1}$ is government bond interest at period $t-1 ; B_{t-1}$ and $B_{t}$ are government debt accumulation to period $t-1$ and $t$ respectively; and $T_{t}$ is the tax revenue in year $t$. Government expenditures plus repayments in the current year (including principal and interest repayments) equal tax revenue for the current year plus new debt issued. Eq. 1 is true for all periods of time.

$$
\begin{aligned}
& \text { At } t+1: B_{t+1}=\left(1+r_{t}\right) B_{t}+G_{t+1}-T_{t+1} \\
& \text { At } t+2: B_{t+2}=\left(1+r_{t+1}\right) B_{t+1}+G_{t+2}-T_{t+2}
\end{aligned}
$$

Substituting (2) into (3), we have:

$$
B_{t+2}=\left(1+r_{t+1}\right)\left[\left(1+r_{t}\right) B_{t}+G_{t+1}-T_{t+1}\right]+G_{t+2}-T_{t+2}
$$

Or:

$$
B_{t}=\frac{B_{t+2}}{\left(1+r_{t+1}\right)\left(1+r_{t}\right)}+\frac{T_{t+1}-G_{t+1}}{\left(1+r_{t}\right)}+\frac{T_{t+2}-G_{t+2}}{\left(1+r_{t+1}\right)\left(1+r_{t}\right)}
$$

Repeating this until $t+s$, we have:

$$
B_{t}=\frac{B_{t+s}}{\prod_{v=1}^{s}\left(1+r_{t+v-1}\right)}+\sum_{v=1}^{s} \frac{T_{t+v}-G_{t+v}}{\prod_{v=1}^{s}\left(1+r_{t+v-1}\right)}
$$

Eq. 1 is considered a minimum condition; government debt in next years is used to pay for the debt owed in the previous years and to finance the budget deficits for the following years. Eq. 1 only shows one-period budget constraint; therefore, we need to take into account the intertemporal constraint.

Discount function is defined as:

$$
P_{t}=\left(\prod_{v=1}^{s}\left(1+r_{t+v-1}\right)\right.
$$

Regarding the no-Ponzi-game condition, which stipulates that the government cannot issue new funded debt to repay both principal and interest of its old debt, the present value of future debt must equal zero in consideration of long-term aspects. 
$\lim _{t \rightarrow \infty} P_{t} B_{t} \leq 0$

From (6) and (8), we have:

$$
B_{t} \leq \sum_{v=1}^{\infty} \frac{T_{t+v}-G_{t+v}}{\prod_{v=1}^{s}\left(1+r_{t+v-1}\right)}
$$

Requirements of budget constraints litmit the primary budget balance: the present value of budget surplus should be greater than or equal to the value of the original debt. It implies that in the long run the government budget will be in surplus for full repayment of liabilities.

Dividing the two sides of Eq. 1 by GDP, we obtain:

$$
\frac{G_{t}}{Y_{t}}+\left(1+r_{t-1}\right) \frac{B_{t-1}}{Y_{t}}=\frac{B_{t}+T_{t}}{Y_{t}}
$$

with $Y_{t-1}\left(1+y_{t}\right)=Y_{t}$ we have:

$$
\begin{aligned}
& \frac{G_{t}}{Y_{t}}+\frac{\left(1+r_{t-1}\right)}{\left(1+y_{t}\right)} \frac{B_{t-1}}{Y_{t-1}}=\frac{B_{t}+T_{t}}{Y_{t}} \\
& x_{t}+\frac{\left(1+r_{t-1}\right)}{1+y_{t}} b_{t-1}=b_{t}
\end{aligned}
$$

where $x$ and $b$ are primary budget deficit and debt-to-GDP ratios respectively; $\mathrm{y}$ is GDP growth rate.

Eq. 9 shows that the debt ratio will increase if at the same period the state budget deficit and nominal interest rate are higher than the growth rate of GDP. In the event of the GDP growth rate being higher than the nominal interest rate, the government can keep the budget deficit stable while the growth rate of future debt declines. In practice, this rarely happens. When the growth rate is greater than the interest rate of capital, the economy would feature dynamic inefficiency (Blanchard, 1991); accumulation of excess capital causes lower interest rates. Therefore, in this circumstance the government should aim at increased debt in order to place the interest rate under pressure, thus controlling the economic growth and reducing the pitfalls of capital accumulation.

State budget constraint can also be realized as follows : 


$$
\Delta b_{t+1}=b_{t+1}-b_{t}=(i-n) b_{t}+x_{t+1}
$$

in which $i$ is a real interest rate and $n$ is the growth rate of real GDP. To reduce the debt rate, the overall budget balance must be higher than the cost of debt:

$$
-x_{t+1} \geq(i-n) b_{t}
$$

Accordingly, if there exists a higher real interest rate than the growth rate of real GDP, the government debt will increase for a limitless time except for the fact that the state budget is in surplus.

In terms of fiscal sustainability defined as a way to keep the debt-to-GDP ratio unchanged over time $\left(\Delta b_{t+1}=0\right)$, Eq. 10a shows that the primary budget surplus is in balance with the difference between the real interest rate and the growth rate of real GDP in the long run. Since tax is a major source of government revenues, Eq. 10a can be rewritten as below:

$$
t=g+b(i-n)
$$

Equations $10 \mathrm{a}$ and $10 \mathrm{~b}$ in combination indicate that fiscal sustainability will be reached once the primary budget surplus or real growth rate is larger than the real interest rate.

Theoretically, the existant literature defines fiscal sustainability as budget operations that are consistent with the intertemporal budget constraint, i.e. to equate the present value of government spending with revenues without restructuring budget expenditures or raising taxation.

\subsection{Empirical models of fiscal and public debt sustainability}

A stream of empirical research has been emerging, capturing fiscal sustainability and pulic debt (Cuddington, 1996; Chalk \& Hemming, 2000; de Haan \& Zelhorst, 1990; Easterly \& Schmidt-Hebbel, 1993; Hakkio \& Rush, 1991; Issler \& Lima, 2000; Sargent, 1999; Trehan \& Walsh, 1991).

Trehan and Walsh (1991) analyzed the sustainability of budget balance and public debt under the no-Ponzi-game condition, attempting to verify the first difference of the public debt. Similarly, Hakkio and Rush (1991) employed cointegration test on the nexus between government expenditures and revenues in an effort to evaluate the fiscal and 
public sustainability. Specifically, Trehan and Walsh (1991) proposed the following equation for testing public debt stationarity:

$$
(1-\operatorname{Lag})^{2} \operatorname{Deb}_{t}=\alpha_{0}+\alpha_{1} t+\delta(1-\operatorname{Lag}) \operatorname{Deb}_{t-1}+\sum_{j=1}^{m} \delta_{j}\left(1-\operatorname{Lag}^{2} \operatorname{Deb}_{t-j}+\varepsilon_{t}\right.
$$

For the hypotheses $H_{0}: \delta_{0}=0$ and $H_{1}: \delta_{0}<0$, if the null hypothesis is rejected, then the process $(1-L a g) D e b_{t-1}$ is stationary, meaning that the hypothesis $H_{1}$ relative to budget balance and sustainable public debt is accepted. In case the null hypothesis is accepted, then the process $(1-L a g) D e b_{t-1}$ is stationary at first difference, implying that the chain of public debt does not satisfy the sustainability condition. However, as for Alfonso (2000), stationarity tests are just a necessary condition for considering the budget balance and public debt sustainability. The cointegration test suggested by Hakkio and Rush (1991) takes the form:

$$
E_{t}+i_{t} \operatorname{Deb}_{t-1}-R_{t}=\sum_{n=0}^{\infty} \frac{1}{(1+\mu)^{n-1}}\left[\Delta R v_{t+n}-\Delta \operatorname{Exp}_{t+n}\right]+\operatorname{Lim}_{n \rightarrow \infty} \frac{D e b_{t}}{(1+\mu)^{n+1}}
$$

For $\operatorname{Exp}_{t}=E_{t}+\left(i_{t}-\mu\right) D e b_{t-1}$ along with the assumption that the real interest rate is stationary with average $\mu$, examining the sustainability of public debt is based on the stationary in no-Ponzi-game condition, which means $\lim _{n \rightarrow \infty}\left(\frac{1}{(1+\mu)^{n+1}}\right) \Delta D e b_{t}=0$. Eq. 15 can be rewritten as follows:

$$
\operatorname{Exp}_{t}-R_{t}=\sum_{n=0}^{\infty} \frac{1}{(1+\mu)^{n-1}}\left[\Delta R v_{t+n}-\Delta \operatorname{Exp}_{t+n}\right]
$$

Eq. 16 implies that the size of public debt sustainability can be measured by a cointegration test on government expenditures and revenues, which can also be represented by the following equation :

$$
R_{t}=\varphi_{1}+\varphi_{2} \operatorname{Exp}_{t}+v_{t}
$$

This technique enables us to verify the stability of fiscal deficit. If the null hypothesis that no cointegration exists between government expenditures and revenues is accepted, it can be concluded that the budget balance and public debt are not sustainable. If the null hypothesis is rejected with $\varphi_{2}=1$, the budget balance and public debt is believed to be sustainable. However, if the null hypothesis is rejected with $\varphi_{2}<1$, the budget 
balance and public debt are no longer sustainable once the growth of expenditures outpaces that of the government revenues.

In sum, prior empirical work has been attempted to establish a link between fiscal sustainability and budget constraints, but this association is also criticized due to the dishonesty of budget constraint announcement. Accountants are accordingly supposed to be clearly defining the overall relation between the amount of government debts and all government revenues as well as other sources. For this reason analyses of fiscal and public debt sustainability in accordance with international norms should be dependent on the assumption that certain adjustments to the levels and sources of tax income or basic expenditures must be consistent with those to the budget constraints, ensuring repayments of all kinds of loans and avoiding defaults.

\section{The landscape of Vietnam's public debt and fiscal sustainability}

Expected to be one of the better developing countries in Asia, Vietnam maintains its average growth rate of $7.5 \%$ in the period of 2000-2008. During the 2008 crisis the slow growth in the national economy could be recorded, being kept at the rate of $6 \%$ between 2008 and 2014. This was deemed the lowest since the 1997 Asian Financial crisis (IMF 2012, 2014).

\subsection{The state of fiscal balance}

According to the 2002 State Budget Law, budget deficit manifests itself in the central budget and can be offset by internal and external borrowings. Budget expenditures cover both principal and interest repayments, whereas budget deficit includes all types of loans to bridge the gap between government expenditures and revenues. Hence, the loans are reflected twice in budget spending (the first time when these loans are used for expenditures and the second time when the principal is repaid at maturity) (MOF, 2014b). It should be worth noting that the IMF's calculations do not include principal repayments in the budget expenditures ${ }^{1}$, and according to international practices, the Vietnam's budget deficit rate is much lower and closer to IMF and ADB statistics. Table 1 shows the differences in the size of state budget deficit due to distinct calculations as reflected by Vietnam's and international standards. 


\section{Table 1}

Vietnam's budget deficit (2001-2013) (as \% of GDP)

\begin{tabular}{|c|c|c|c|c|c|c|c|c|c|c|c|c|c|}
\hline & 2001 & 2002 & 2003 & 2004 & 2005 & 2006 & 2007 & 2008 & 2009 & 2010 & 2011 & 2012 & 2013 \\
\hline $\begin{array}{l}\text { MOF } \\
\text { (incl. } \\
\text { debt } \\
\text { principal) }\end{array}$ & 2.5 & 2.5 & -4.9 & -4.9 & -4.86 & -4.99 & -5.65 & -4.58 & -6.9 & -5.5 & -4.9 & -4.8 & -6.6 \\
\hline $\begin{array}{l}\text { MOF } \\
\text { (excl. } \\
\text { debt } \\
\text { principal) }\end{array}$ & & & -1.8 & -1.1 & -0.9 & -0.9 & -1.76 & -1.81 & -3.69 & -2.36 & -3.14 & -3.1 & -3.3 \\
\hline IMF & -2.78 & -2.35 & -3.25 & -0.19 & -1.31 & 0.3 & -2.18 & -0.54 & -7.17 & -2.8 & -1.1 & -6.8 & -5.6 \\
\hline ADB & -3.5 & -2.3 & -2.2 & 0.1 & -1.0 & 1.2 & -0.9 & 0.6 & -4.2 & -2.1 & -0.5 & -4.4 & -4.7 \\
\hline
\end{tabular}

Source: IMF (2012, 2014), ADB (2014), and MOF (2014a)

Based on the IMF data from 2001 to present, Vietnam has experienced periods of fiscal expansion, fiscal consolidation, and then another fiscal expansion in an active manner. Firstly, during the period of 2001-2003 budget deficit expanded to a rate of about $3 \%$ of GDP. A short time later the budget deficit was cut, thus creating a surplus in 2006. Nevertheless, the following two years witnessed an extention of spending, causing the fiscal situation, once again, to plunge into deficit. The severe fiscal imbalance occurred in 2009, when the economic stimulus package valued at $5 \%$ of GDP coincided with a decline by $2 \%$ in oil revenue and pushed the budget deficit to a rate of $7 \%$ of GDP. Since then there has been some sharp fluctuations in the budget deficit (see Table 1), while the economy has been exhibiting no sign of recovery.

\subsection{A rise in public debt}

Debt ratio is one of the important indicators of fiscal sustainability, despite the fact that no general consensus is reached on 'safe' limits. It is believed by the Government that the public debt ratio still reveals a safe limit because of not exceeding the rate of $60 \%$ (MOF, 2014a) ${ }^{2}$. Approached in a narrow sense, the definition of sovereign debt in view of the 2009 Law on Public Debt Management ignores a close relation between the state budget and that of public sector units. As such, the size of public debt would cover government debt, government-guaranteed debt, and debt owed by local authorities. After Vietnam and Russia reached an agreement on the handling of the former debts owed to the USSR (arising from the 1980s) in 2000, the size of Vietnam's public debt was 
recorded at $32.57 \%$ of GDP by 2001 . Figure 2 illustrates a rapid rise in the national public debt over 2001-2013, from 32\% in 2001 to $58.66 \%$ of GDP in 2014. This means an increase by more than 80 percentage points.

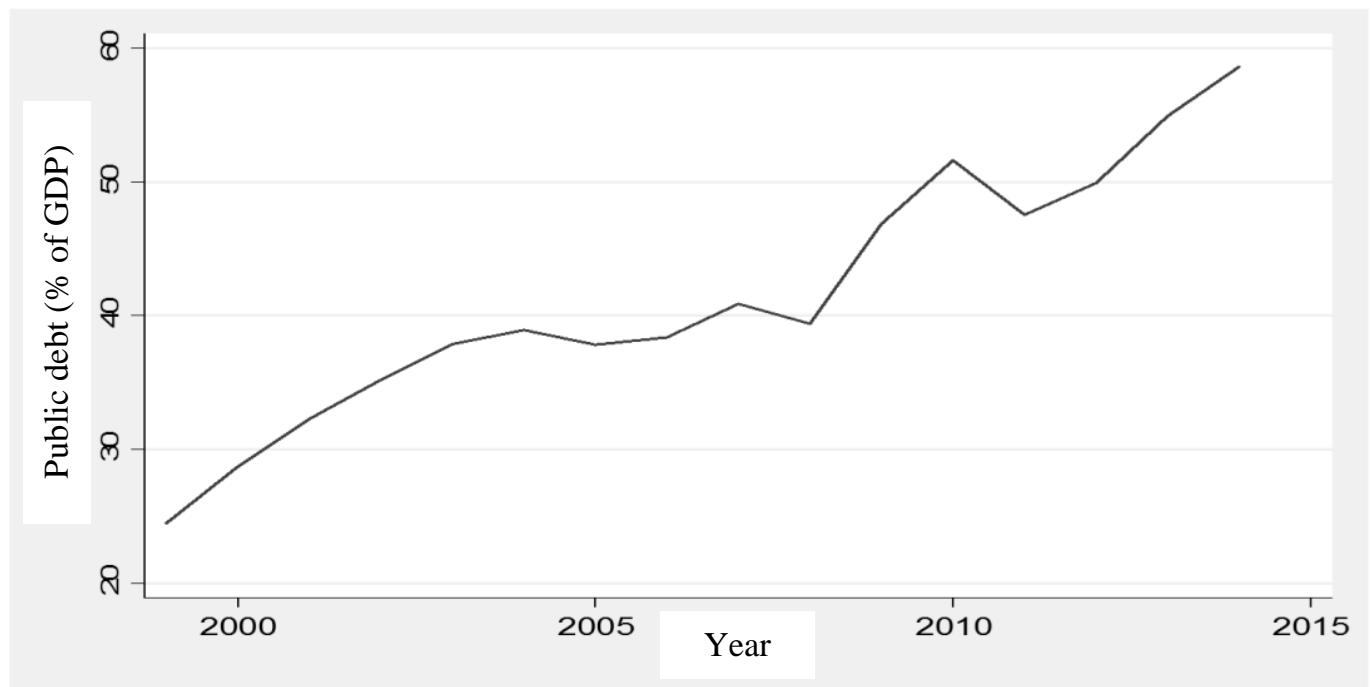

Figure 2. Sizes of public debt in accordance with MOF statistics (as \% of GDP) Source: MOF (2014a)

3.3. Differences between Vietnam's and international norms in measuring fiscal indicators

Public debt, as stated by IMF (2010b), is understood to be repayment obligation of the public sector, which is in turn defined as the one to include government and public sector organizations. The fiscal policy and public debt are formally approached by Vietnamese scholars in a narrow sense, and are not conforming to international norms (IMF, 2010b, 2012). As a result, most official announcements in Vietnam lack clear statements of fiscal sustainability, whereas official fiscal datasheet almost systematically excludes the items of expense and important budget collection such as the items of expense for national investment supported by ODA and unspoken debts of public debt (Adam, 2012). In addition, as loans from government bond issuance for funding a few target projects and costs of capital restructuring among SOEs are not listed in budget balance and/or public debt, the buget balance fails to fully reflect the deficit.

Given economic operations, the operated expansion of an official debt guarantee is not rightly concerned in the fiscal report datasheet (Adam, 2012). There has been an 
increasing trend in guaranteed debts until recently, from USD4 billion in 2008 to USD14-15 billion within two years of 2011 and 2012. All of these debts are mostly from commercial debts owed by SOEs in the fields of transportation and energy. While the guanranteed debts pose a threat to fiscal sustainability, the Government's guarantee for this kind of debts should involve "moral hazard." The SOEs are thus less motivated to minimize the risk in assurance of timely repayment for debts at maturity.

In institutional relations there has been no concern over SOEs' contingent liabilities in the state budget besides the debts owed by state-owned commercial banks (SOCBs), social policy banks, and other economic units like social insurance funds. The World Bank Group $(2010,2011)$ notified financial health and liquidity of many Vietnam's banks, regarding: (i) level of solvency in the banking sector; and (ii) the probability of the government in officially financing SOCBs and joint-stock commercial banks, which supports them with repayments or system restructuring. It is not surprising that the Government is reluctant to finance the debts of financial institutions in case the issue of "moral hazard" can be evaded (Adam, 2012). By this aprroach Table 2 shows the sizes of Vietnam's public debt, including a total of government debt and SOEs' debts of up to $129 \%$ of GDP in 2011 and 102\% of GDP in 2012. Particularly, the size of debt owed by SOEs reaches the rate of approximately $51 \%$ of GDP.

\section{Table 2}

Vietnam's public debt in different approaches (2011-2013)

\begin{tabular}{lccc}
\hline \multicolumn{1}{c}{ Indicator } & 2011 & 2012 & 2013 \\
\cline { 2 - 4 } & \% of GDP & \% of GDP & \% of GDP \\
\hline Public debt by Vietnam's definition & 54.9 & 50.8 & 54.2 \\
Government debt & 52.1 & 40.1 & 42 \\
Debt guaranteed by government & 14.0 & 10.2 & 11 \\
Local government debt & 0.7 & 0.5 & 1.5 \\
Public debt by international definition & 128.9 & 101.8 & NA \\
Government debt & 66.8 & 50.8 & \\
SOEs' debt (internal and external) & 62.1 & 51 & NA \\
\hline
\end{tabular}

Source: MOF statistics by 2014 and 2015 


\section{Evaluation of fiscal and public debt sustainability in Vietnam}

\subsection{Empirical analyses}

\subsubsection{Research data}

In this section we examine Vietnam's fiscal and public debt sustainability, employing data retrieved from IMF and ADB databases. Table 3 summarizes statistical data of the variables used for assessment. The highest rate of budget expenditures as a percentage of GDP is $29.91 \%$, whereas the lowest rate is $15.74 \%$. The highest rate of budget revenues as a percentage of GDP is $26.71 \%$, whereas the lowest rate is $10.48 \%$. While the highest rate of public debt, including debt owed to the Soviet Union (SU), is projected at $450.64 \%$ of GDP, the highest and lowest rates of public debt, excluding debt owed to SU, are $54.97 \%$ and $4.78 \%$ of GDP respectively.

\section{Table 3}

Statistical description of the variables used for assessing fiscal and public debt sustainability

\begin{tabular}{|c|c|c|c|c|c|c|}
\hline Variable & $\begin{array}{c}\text { No of } \\
\text { observations }\end{array}$ & Mean & Std. dev. & Minimum & Maximum & Source \\
\hline $\begin{array}{l}\text { GDP per capita } \\
\text { growth }\end{array}$ & 28 & 0.048 & 0.016 & 0.004 & 0.074 & IMF \\
\hline $\begin{array}{l}\text { Budget revenue } \\
\text { (\% of GDP) }\end{array}$ & 29 & 20.842 & 4.759 & 10.486 & 26.719 & ADB \\
\hline $\begin{array}{l}\text { Budget } \\
\text { expenditure (\% } \\
\text { of GDP) }\end{array}$ & 29 & 23.739 & 3.253 & 15.749 & 29.914 & $\mathrm{ADB}$ \\
\hline $\begin{array}{l}\text { Public debt } \\
\text { (including debt } \\
\text { owed to SU) } \\
\text { (\% of GDP) }\end{array}$ & 24 & 99.544 & 106.267 & 32.277 & 450.64 & IMF \\
\hline $\begin{array}{l}\text { Public debt } \\
\text { (excluding debt } \\
\text { owed to SU) } \\
\text { (\% of GDP) }\end{array}$ & 24 & 30.088 & 15.441 & 4.785 & 54.978 & IMF \\
\hline
\end{tabular}




\subsubsection{Stationarity test on public debt}

Table 4 presents the results of stationarity test for the variable of public debt/GDP over the 1990-2013 period. The data collected for public debt are according to the two criteria: with inclusion of the debt owed to the former SU countries, estimated through transferable ruble emerging from the 80s and earlier, and without inclusion, which is to be addressed in this research due to its proper reflection of the public debt in Vietnam during its economic reform since 1990 . We perform unit root/stationarity test on the public debt, using ADF statistic, including trend and no trend instances. The ADF test is applied to the regressions, realized by the following forms:

$\Delta Y_{t}=\beta_{1}+\delta Y_{t-1}+u_{t}$

or:

$\Delta Y_{t}=\beta_{1}+\beta_{2} t+\delta Y_{t-1}+u_{t}$

in which $\mathrm{t}$ is a trend of time variable. The null hypothesis is $\delta=0$ or $\rho=1$, meaning $\mathrm{Y}$ has a unit root ( $\mathrm{Y}$ is non-stationary). In contrast, the hypothesis $\mathrm{H}_{1}$ is $\delta \neq 0$ or $\rho<1$, meaning $\mathrm{Y}$ does not have a unit root (Y is stationary). Table 4's results indicate that public debt (without inclusion of debt owed to SU) is non-stationary, with trend and no trend. Based on the argument from Trehan and Walsh (1991), the case of Vietnam's public debt is unsustainable.

\section{Table 4}

Results of ADF test statistic on public debt (\% of GDP)

\begin{tabular}{lccc}
\hline Variable & Lag length & \multicolumn{2}{c}{ ADF statistic } \\
\cline { 3 - 4 } & & No trend & With trend \\
\hline $\begin{array}{l}\text { Public debt (\% of GDP) (without } \\
\text { inclusion of debt owed to SU) }\end{array}$ & 0 & -0.437 & -2.517 \\
\hline $\begin{array}{l}\text { Public debt (\% of GDP) (with } \\
\text { inclusion of debt owed to SU) }\end{array}$ & 0 & $-12.825 * * *$ & $-8.047 * * *$ \\
\hline
\end{tabular}

Note: MacKinnon values for rejection of hypothesis of a unit root at $1 \%$ level (***)

4.1.3. Cointegration test on budget revenue and expenditure

We also perform cointegration test on budget expenditure (\% of GDP) and revenue (\% of GDP), whereby the variable of budget revenue reveals the government's ability to 
meet spending demands in the event of budget constraints in a narrow sense. First, a stationarity test is carried out on both budget revenue and expenditure. The results demonstrate that the budget expenditure is stationary, with trend and with no trend at zero difference $\mathrm{I}(0)$ and $1 \%$ and $5 \%$ significance levels respectively, while the budget revenue is stationary with trend and with no trend at first difference $\mathrm{I}(1)$ with the least significance level of $1 \%$ (see Table 5). The budget revenue and expenditure are shown to be stationary at different differences. Next, for cointegration testing, we employ Engle-Granger two-step method.

\section{Table 5}

Results of ADF test statistic on budget revenue and expenditure (\% of GDP)

\begin{tabular}{lccc}
\hline \multirow{1}{*}{ Variable } & Lag length & \multicolumn{2}{c}{ ADF statistic } \\
\cline { 3 - 4 } & & With no trend & With trend \\
\hline $\begin{array}{l}\text { Budget revenue }(\% \text { of GDP) } \\
\begin{array}{l}\text { Budget expenditure } \\
(\% \text { of GDP })\end{array}\end{array}$ & 0 & -1.274 & -1.428 \\
$\begin{array}{l}\Delta \text { Budget revenue } \\
(\% \text { of GDP })\end{array}$ & 0 & $-3.367 * *$ & $-5.943 * * *$ \\
\hline
\end{tabular}

Note: MacKinnon values for rejection of hypothesis of a unit root at $1 \%$ level (***) and 5\% level (**)

Tables 6 and 7 report the estimated results of the long-term relation between budget revenue and expenditure and stationarity test on residual parts. The regression coefficient of the budget revenue is 0.503 (less than 1) at $1 \%$ significance level, and the residuals of long-term regression are stationary with trend and no trend at $5 \%$ significance level. Wald, Durbin-Watson, and LM tests suggest that using the models is suitable, and no autocorrelation occurs. Based on these results, we can reject the hypothesis that there exists no cointegration between the budget revenue and expenditure. As stated, the regression coefficient of the budget revenue is less than 1 , implying that the increased demand for government spending might fundamentally not be offset by increase in budget revenues in the long run. 


\section{Table 6}

Estimated results of long-term relation between budget revenue and expenditure

Dependent variable: budget revenue (\% of GDP)

\begin{tabular}{lcccc}
\hline \multicolumn{1}{c}{ Variable } & Regression coef. & t-statistic & Adjusted $\mathrm{R}^{2}$ & Prob $>\mathrm{F}$ \\
\hline Budget expenditure & 0.503 & $3.93 * * *$ & 0.9002 & 0.0000 \\
L1. budget revenue & 0.765 & $4.52 * * *$ & \\
L2. budget revenue & -0.140 & -0.95 & \\
Cons & -4.54 & $-1.95 *$ \\
Wald test & $\mathrm{F}(1,23)=0.89 \quad$ Prob $>\mathrm{F}=0.3540$ \\
DW test & \multicolumn{4}{c}{ Prob $>\mathrm{F}=0.6276$} \\
Breusch-Godfrey LM test & Prob $>\mathrm{chi}^{2}=0.5878$ \\
\hline
\end{tabular}

Note: $(*)$ and $(* * *)$ denote significance levels of $10 \%$ and $1 \%$ respectively.

\section{Table 7}

Results of stationarity test on residuals

\begin{tabular}{ccc}
\hline \multirow{2}{*}{ Variable } & \multicolumn{2}{c}{ ADF statistic } \\
\cline { 2 - 3 } & With no trend & With trend \\
\hline Residuals & $-4.480 * *$ & $-4.371 * *$ \\
\hline
\end{tabular}

Note: MacKinnon values for rejection of hypothesis of a unit root at 5\% level (**)

Table 8 presents the estimated results attained from the use of ECM for budget revenue-expenditure nexus over the 1985-2013 period. As given by Table 8, the shortterm difference between the budget revenue and expenditure is higher than $55 \%$, whereas EC(-1) $=-0.104$ is not statistically significant, thereby implying that no equilibrium can be reached in adjusting the revenue-expenditure relation in both short and long terms. 


\section{Table 8}

Estimated results of ECM

Dependent variable: $\Delta$ budget revenue (\% of GDP)

\begin{tabular}{lcccc}
\hline \multicolumn{1}{c}{ Variable } & Regression coef. & t-statistic & Adjusted $\mathrm{R}^{2}$ & Prob $>\mathrm{F}$ \\
\hline $\begin{array}{l}\Delta \text { Budget } \\
\text { expenditure }\end{array}$ & 0.445 & $3.52 * *$ & 0.2969 & 0.0067 \\
EC(-1) & -0.104 & & & \\
Cons & 0.201 & -0.43 & & \\
\hline
\end{tabular}

Note: $(* *)$ denotes significance level of $5 \%$.

We then examine the response of budget revenue to expenditure. By using AIC, HQIC, and SBIC, we choose the optimal lag length of 1 . The response function, as illustrated by Figure 3, indicates that the revenue shows a declining tendency after a certain period and then returns to equilibrium. To this extent a rise in demand for budget expenditures cannot be balanced by increased budget revenues. The results from Granger causality test confirm that the budget expenditure Granger-causes the revenue, and is significant at $1 \%$ level, whereas the same variable, in a reverse case, is not statistically significant. This means that its variance does affect the budget revenue (Table 9).

\section{Table 9}

Results of Granger causality test

\begin{tabular}{lccc}
\hline Granger causality & $\mathrm{Chi}^{2}$ & Df & Prob > chi \\
\hline Revenue -> expenditure & 2.6107 & 1 & 0.106 \\
Expenditure -> revenue & 17.985 & 1 & $0.000 * * *$ \\
\hline
\end{tabular}

Note: $(* *)$ denotes significance level of $1 \%$.

Accordingly, the issue of fiscal and public debt sustainability cannot be ensured, as were underpinned by the empirical findings. The public debt reveals an increasing tendency while there exists no cointegration between budget revenue and expenditure. We are also aware that the rate of budget revenues tends to decline; consequently, it hardly meets the demand for spending. As remarked by IMF (2008, 2010, 2014), Vietnam's tax buoyancy declines in spite of the Government's continued efforts to 
expand the tax base. In the event of economic growth defined as being unimproved, expansionary fiscal policy to adjust the economic cycle may entail a growth in public debt and fiscal deficit (IMF, 2014).

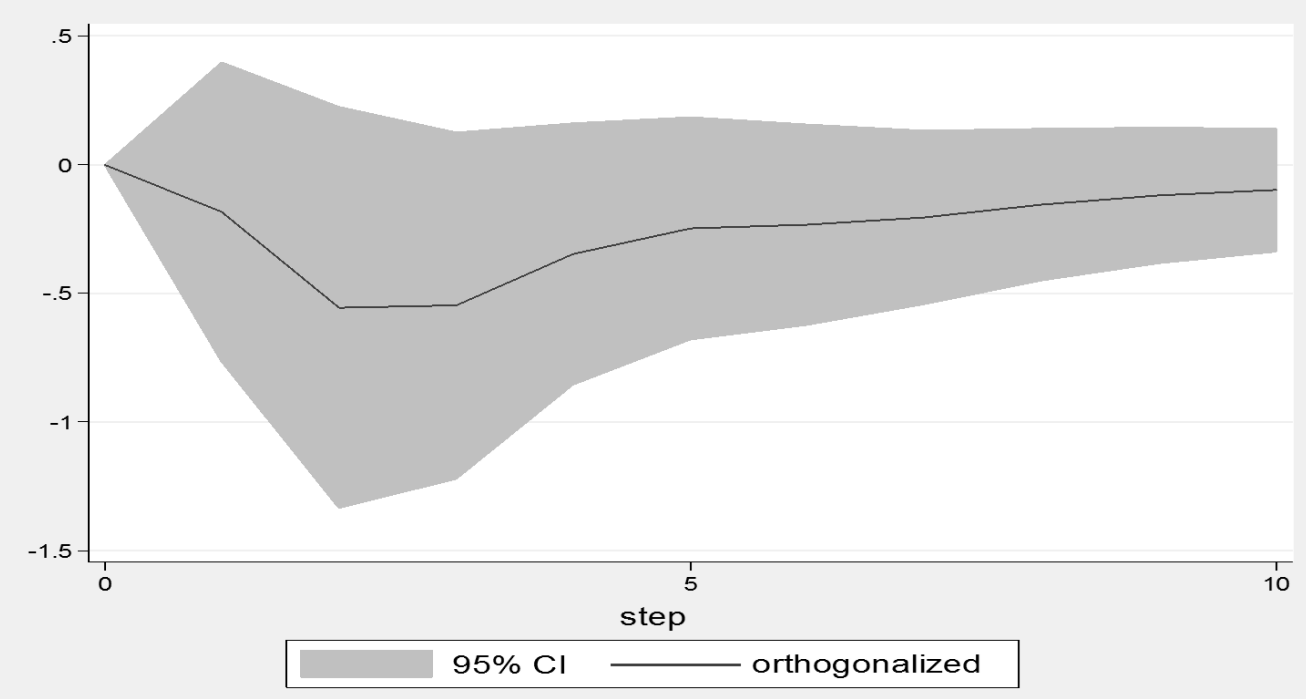

Figure 3. Response of budget revenue to expenditure

\subsection{Evaluation of fiscal vulnerability and public debt sustainability}

The empirical results in this study also hint that Vietnam's fiscal policy and public debt have risen to many challenges related to the systematic sustainability. However, these can be biased as analysis of fiscal sustainability is also grounded on the definition of debt. In this section we discuss several sustainability-related aspects, namely structural fiscal balance, budget revenue/expenditure structure, fiscal management practices, accounting standards, and fiscal measurement.

In structural fiscal balance debt repayment has a tendency to increase

In fiscal balancing debt repayment tends to rise, causing increased fiscal deficit and public debt (Table 10). Recent years have witnessed debt repayment, as a percentage of GDP, reaching $1.5 \%$, accounting for $25 \%$ of fiscal deficit, and this has been conducive to a considerable reduction in capital financing for economic restructuring. 


\section{Table 10}

Basic fiscal balance and debt repayment (\% of GDP)

\begin{tabular}{lccccccc}
\hline Indicator & 2009 & 2010 & 2011 & 2012 & 2013 & 2014 & $\begin{array}{l}2015 \\
\text { (est.) }\end{array}$ \\
\hline Public debt & 46.9 & 48.4 & 46.7 & 48.5 & 51.6 & 54.8 & 57.1 \\
Overall fiscal deficit & -6.0 & -2.8 & -1.1 & -6.8 & -5.6 & -6.6 & -6.1 \\
Basic fiscal deficit & -4.9 & -1.6 & -0.0 & -5.6 & -4.2 & -5.1 & -4.6 \\
Debt repayment & 1.1 & 1.2 & 0 & 1.2 & 1.4 & 1.5 & 1.5 \\
\hline
\end{tabular}

Source: IMF (2014)

Fiscal vulnerability: The issue of budget revenues and expenditures

Regarding budget revenues, the vulnerability depends largely on the income from crude oil, SOEs, and tariffs, and also land income (IMF, 2010, 2014; Rosengard et al., 2010). Table 11 indicates that the crude oil revenue occupies a crucial position in budget balance, contributing over 50\% to the balance in the period between 2010 and 2011. Yet, by 2014-2015 the contribution tends to be less effective due to a decline in the global crude oil price.

Overall, Vietnam's budget revenues seem utterly vulnerable to shocks of domestic and international markets. Economic recession weakens the tax base, bringing about a reduction in tax revenue and total budget revenues, from 23\% of GDP in 2007 to $22 \%$ and $20 \%$ of GDP in 2009 and 2012 respectively. It is less likely for a recovery to the 2007 's rate as a result of the tax cut policy entailing decline in various revenue sources in the coming years.

\section{Table 11}

Fiscal balance in Vietnam

\begin{tabular}{cccccccc}
\hline \multicolumn{1}{c}{ Indicator } & 2009 & 2010 & 2011 & 2012 & 2013 & 2014 & $\begin{array}{l}2015 \\
\text { (est.) }\end{array}$ \\
\hline $\begin{array}{l}\text { Fiscal deficit (with } \\
\text { crude oil revenue) }(\%\end{array}$ & -6.0 & -2.8 & -1.1 & -6.8 & -5.6 & -6.6 & -6.1 \\
of GDP)
\end{tabular}




\begin{tabular}{lccccccc}
\hline \multicolumn{1}{c}{ Indicator } & 2009 & 2010 & 2011 & 2012 & 2013 & 2014 & $\begin{array}{l}2015 \\
\text { (est.) }\end{array}$ \\
\hline $\begin{array}{l}\text { Fiscal deficit } \\
\text { (without crude oil } \\
\text { revenue) (\% of GDP) }\end{array}$ & -8.3 & -4.8 & -4.0 & -9.4 & -7.6 & -7.7 & -6.9 \\
$\begin{array}{l}\text { Absolute difference } \\
(2-1)\end{array}$ & 2.3 & 2 & 2.9 & 2.6 & 2 & 1.1 & 0.8 \\
Difference (\%) & $27.7 \%$ & $50 \%$ & $72.5 \%$ & $27.6 \%$ & $28.5 \%$ & $14.2 \%$ & $12 \%$ \\
\hline
\end{tabular}

Source: IMF (2014)

In terms of spending, potential vulnerability involves commitments to the implementation of universal health insurance by 2015 and the expasinary scope of social insurance, aiming to mitigate the adverse impact on households in coping with income shocks. These commitments, as stated by Adam (2012), might extend budget expenditures over time. Further potential vulnerability relates to the policy on public investment expenditures and decentralization of public investment management (National Assembly's Economic Committee \& UNDP, 2013). A general trend has recently emerged, reflecting high decentralization, increased real power, and improved local initiative in resource mobilization and capital budget allocation and use for public investment activities. However, failures in the budget balance currently arise in more than 50 provinces, where conducting the majority of investment projects must rely on grants from the central government.

Fiscal vulnerability: The issue of poor fiscal management

There has been a lack of solid basis in budget assumptions and projections. Increasing pressures on public spending has led up to widespread violations against legislative acts on public expenditures. The spending rate surpasses the one reflected in budget estimates, increasing from $31 \%$ to $42 \%$ over the years $2007-2011$ (Figure 4). The rapidly increasing size of public investment is conducive to a rise in recurrent spending which dominates other national welfare and people's livelihood expenditures. The restructuring of public investment in these years has basically been characterized as being situational and short-term directed with its primary aim to handle the problem of investment decisions outpacing capital balancing or asynchronous investment rather than to establish a new institution that improves efficiency in the systematic management and use of state capital. 


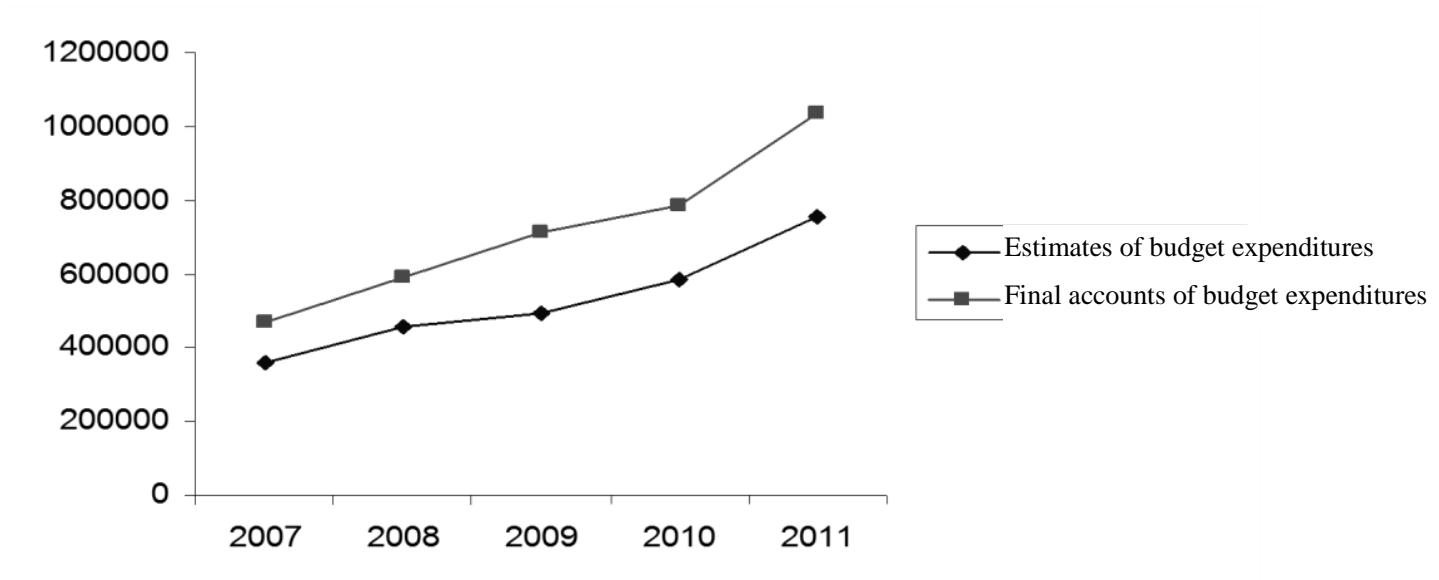

Figure 4. Differences between estimates and final accounts of budget expenditures Source: MOF (2014a)

Fiscal vulnerability: The issue of accounting standards and fiscal measurement

The above arguments hightlight the practices of fiscal and public debt measurement which imply potential fiscal vulnerability due to: (i) failures to cover all major aspects; and (ii) existence of contingent liabilities in public sector units. One key challenge to the Government is "any lack of transparency about the size of these potential contingencies" (Adam, 2012). In addition, the current state of macroeconomic development voices concerns over the financial health of SOEs and SOCBs.

According to IMF (2010), bad debt overshadows other kinds of debt among the public sector units. Together with the expansion of contingencies as well as public debt, the fiscal space has narrowed sharply, insufficiently meeting the basic needs of society. The potential contingencies from SOEs and financial sector, whose size is unknown, would pose additional risk to the fiscal and public debt sustainability (IMF, 2012). Another concern is that universal fiscal rules and discipline have scrarcely been conformed to in Vietnam. Domestic debts owed by SOEs are settled by the Government in cases of supplementary capital financing, debt freezing, debt rescheduling, debt swap, and debt remission and/or forgiveness. All these forms ultimately boost the spending, provoking the state's frequent budget deficit crisis.

\section{Conclusion and policy implications}

\subsection{Conclusion}


In short, we have performed an analysis of Vietnam's fiscal and public debt sustainability, adopting several approaches suggested from Trehan and Walsh (1991) and Hakkio and Rush (1991) for a cointegration test on the government revenueexpenditure nexus. Additionally, on examining the differences between national and international norms along with a few indicators that measure the sustainability of public debt as well as potential fiscal risk, we argue that:

(i) Discrepancies arise between national and international norms in measuring the indicators of fiscal sustainability - these can be subject to insufficient assessment of the relation between the Government and public sector units in association with the state's functions in the national economy;

(ii) The Vietnam's fiscal and public debt situation reveals little sustainability as were confirmed by the empirical findings; the budget revenue and expenditure show no existence of cointegrating relationship. Despite the conduct of tax policy reform and a shift toward extending the tax base, no improvement in tax buoyancy could be realized. As a result, budget revenues hardly satisfy the demands for spending, causing an increase in fiscal deficit (IMF, 2014); and

(iii) The size of fiscal deficit and public debt expands rapidly. Interest payments tend to rise, while the increasingly narrow fiscal space can be identifiable, hardly coping with growing demands by community. Increased risk, involved with potential contingencies from SOEs and other financial sectors, whose size is uncontrollable, may also be posed to the national fiscal policy and public debt management (Adam, 2012; IMF, 2014).

\subsection{Implications}

In June 2015 State Budget Law was approved by the National Assembly, overcoming the double counting of debt in budget balance and streamlining local budget deficit. However, implicit debts such as those owed by SOEs or in publicprivate partnership and social security programs need to be incorporated into the concept of public debt. This means that the Government should be fully aware of the risks of public debt. Structuring of the banking system and SOEs eventually requires certain public funding (Adam, 2012; IMF, 2014). 
The results indicate that the revenue policy cannot catch up with the growth in demands for budget expenditures. Most of the revenue sources are from crude oil, SOEs, trading tariffs, and land income (IMF, 2010; IMF, 2014; Rosengard et al., 2010). Hence, improving the Vietnam's tax system should aim at the diversification and expansion of tax base that facilitates sustaintable revenue sources. A simple tax system, as well as a broadened tax base, as shown by international experience, would offer better elasticity.

Particularly, since the reason for unsustainable fiscal policy and public debt lies in the rapidly increasing spending, it is essential to: (i) ensure the sustainability of social expenditures and address the social inequality; (ii) promote the practice of investment spending in accordance with potential growth, adjust the diversification public investments under the principle of fiscal sustainability, and provide a more effective meachnism for strict control over local public investments; and (iii) rationalize the wage policy in addition to enhancing the quality of public services provided for community.

While the fiscal regulations and discipline should be strengthened, there is a need to reorganize the information system on public debt in a logical manner and improve legal frameworks on the rights and responsibilities to disseminate and/or utilize information provided by government agencies at different levels. Furthermore, establishing a modern information network is to support an efficient link between central and local debt management agencies, on-lending agencies, and investors using foreign capital. The information on differeent kinds of public debt, including both domestic and foreign debts, should be timely publicized to enhance the effectiveness of social supervisions

\section{Notes}

${ }^{1}$ State budget deficit is calculated by total state budget revenues (excluding collection of debts) minus total expenditures (excluding debt principal repayments).

${ }^{2}$ According to the national strategies on public debt and foreign debt in the period of 2011-2020 and visions to 2030, the public debt (including government debt, government-guaranteed debt, and local government debt), until 2020, does not exceed 65\% of GDP; particularly, the government debt and the foreign debt do not go beyond 55\% and 50\% of GDP respectively (Vietnamese Government, 2012). 


\section{References}

Abdelatif, L., \& Shehata, A. (2006). Fiscal sustainability and the role of the state: A new analytical framework. Retrieved from http://www.ecomod.net/sites/default/files/document...\%20/ ecomod2006/1231.pdf

Adam, C. (2012). Public debt sustainability and fiscal vulnerability in Viet Nam. In B. Ferrarini, R. Jha \& R. Amayandi (eds.), Public debt sustainability in developing Asia (pp. 170-192). Copublication of the Asian Development Bank and Routledge.

ADB (2014). Key indicators for Vietnam. Asian Development Bank.

Afonso, A., \& Gestão, E. (2000). Fiscal policy sustainability: Some unpleasant European evidence (ISEG Working Paper No. 12/2000/DE/CISE). Lisbon, Portugal: Department of Economics, Instituto Superior de Economia e Gestao.

Allen. R. D. (2013). US government spending, the national debt, and the role of accounting educators. Journal of Accounting Education, 31(3), 215-231.

Alvarado, C. D., Izquierdo, A., \& Panizza, U. (2004). Fiscal sustainability in emerging market countries with an application to Ecuador (Working Paper No. 511). Washington, DC: Research Department, Inter-American Development Bank.

Blanchard, O., Chouraqui, J. C., Hagemann, R. P., \& Sartor, N. (1990). The sustainability of fiscal policy: New answers to an old question. OECD Economic Studies, 15(Autumn), 8-36.

Blejer, M. I., \& Cheasty, A. (1991). The measurement of fiscal deficits: Analytical and methodological issues. Journal of Economic Literature, 29(4), 1644-1678.

Burnside, C. (2003). Some tools for fiscal sustainability analysis. Retrieved from http://people.duke.edu/ acb8/fsb/fsb_3rev.pdf

Catrina, I. L. (2012). The failure of fiscal consolidation through "budget cuts". Procedia Economics and Finance, 3, 367-374.

Chalk, N., \& Hemming, R. (2000). Assessing fiscal sustainability in theory and practice (IMF Working Paper, WP/00/81). Washington, DC: International Monetary Fund.

Cuddington, J. (1996). Analysing the sustainability of fiscal deficits in developing countries. Retrieved from http://inside.mines.edu/ jcudding/papers/Sustain/Sustainability(9.3.99).pdf

de Haan, J., \& Zelhorst, D. (1990). The impact of government deficits on money growth in developing countries. Journal of International Money and Finance, 9(3), 455-469. http://dx.doi.org/10.1016/0261-5606(90)90022-R

Easterly, W., \& Schmidt-Hebbel, K. (1993). Fiscal deficits and macroeconomic performance in developing countries. World Bank Research Observer, 8(2), 211-237.

Gunter, B.G., 2003: Achieving long-term debt sustainability in all heavily indebted poor countries (HIPCs). Retrieved from http://g24.org/wp-content/uploads/2014/03/Gunter-1.pdf 
Hakkio, C. S., \& Rush, M. (1991). Is the budget deficit 'too large'? Economic Inquiry, 29, 429-445. IMF. (2010a). Vietnam 2010 article IV consultation-Staff report and public information notice. (IMF Country Report, No. 10/281). Washington, DC: International Monetary Fund.

IMF. (2010b). Public sector debt statistics-Guide for compliers and users. Washington, DC: International Monetary Fund.

IMF. (2012). Vietnam 2010 article IV consultation-Staff report and public information notice. Washington, DC: International Monetary Fund.

IMF. (2014). Vietnam: 2014 article IV consultation-Staff report; press release; and statement by the Executive Director for Vietnam (IMF Country Report No. 14/311). Washington, DC: International Monetary Fund.

Issler, J., \& Lima, L. (2000). Public debt sustainability and endogenous seignorage in Brazil: Time series evidence from 1947-1992. Journal of Development Economics, 62(1), 131-147.

Mendoza, E., \& Oviedo. P. M. (2003). Public debt sustainability under uncertainty. Washington, DC: Inter-American Development Bank.

MOF. (2014a). Publicizing of state budget (in Vietnamese). Retrieved from http://mof.gov.vn/portal/page/portal/mof_vn/1351583

MOF. (2014b). A new method for calculating budget deficit: Reducing deficit and upgrading transparency (in Vietnamese). Retrieved October 13, 2014 from http://thoibaotaichinhvietnam.vn/pages/nhip-song-tai-chinh/2014-10-13/tinh-boi-chi-theo-cachmoi-giam-boi-chi-tang-minh-bach-14260.aspx

National Assembly's Economic Committee., \& UNDP. (2013). Public debt and sustainability in Vietnam: Past, present, and future (in Vietnamese). Hanoi, Vietnam: Tri Thuc Publishing House.

Nguyen, Q. T. (2013). Reducing the budget deficit sustainably in Vietnam: Pathway to 2020. The Asian Conference on Sustainability, Energy \& the Environment 2013. Official Conference Proceedings 2013.

Rosengard, J. K., Tran, T. Q. G., Dinh, V. T. N., Huynh, T. D., \& Chauvin, J. P. (2011). The unintended consequences of successful resource mobilization: Financing development in Vietnam. Hanoi, Vietnam: United Nations Development Programme and the Fulbright Economics Teaching Program.

Sargent, T. (1999). A primer on monetary and fiscal policy. Journal of Banking and Finance, 23(8), 1463-1482.

The World Bank Group. (2002). Global development finance. Retrieved October 21, 2014 from http://siteresources.worldbank.org/GDFINT/Resources/334952-1257197834412/FullTextVolume1.pdf

The World Bank Group. (2010). Taking stock: An update on Vietnam's recent economic developments (Consultative Group Meeting). Washington, DC: The World Bank Group. 
The World Bank Group. (2011). Taking stock: An update on Vietnam's recent economic developments (Consultative Group Meeting). Washington, DC: The World Bank Group.

The World Bank Group. (2013). Review: Updating Vietnam's economic development (in Vietnamese).

Retrieved from

http://www.worldbank.org/vi/country/vietnam/publication/takingstockdecember2014

Trehan, B., \& Walsh, C. E. (1991). Testing intertemporal budget constraints: Theory and applications to US federal budget and current account deficits. Journal of Money, Credit, and Banking, 23(2), 206-223.

Vietnamese Government. (2012). Decision No. 958/QD-TTg approving the public debt and national foreign debt. Retrieved from http://thuvienphapluat.vn/van-ban/Tai-chinh-nha-nuoc/Decision-No958-QD-TTg-approving-the-public-debt-and-national-foreign-debt-145154.aspx 